\title{
Assessment of Newspaper Advocacy for Rural Development and Environmental Education in Nigeria
}

\author{
Ifenkwe, G.E \\ Department of Rural Sociology and Extension \\ Micheal Okpara University of Agriculture, Umudike \\ E-mail:godwinifenkwe@yahoo.com
}

\begin{abstract}
This study investigated the extent to which the print media, and particularly the newspapers, faced the challenge of informing, educating and championing the rights of the people in rural development and environmental education in 2006. It analyzed five leading national newspapers for a period of twelve months to ascertain their level of coverage and reportage of environmental and rural development information and specialty events. Rural development news coverage was highest (31.48\%) in the fourth quarter, and least in the third quarter $(17.79 \%)$ of the year. Sixty nine percent of rural development information/news appeared as features, while others were presented as editorials (13.04\%), advertorials (9.27\%) and pictorials (8.38\%). The Sun newspapers (23.65\%) could easily pass as the best print medium in reporting environmental and rural development news, followed by The Punch (22.5\%) and The Champion (21.3\%) newspapers. The Sun newspapers also exhibited consistent leadership in promoting activities in the health and population / family planning sub-sectors, while The Champion disseminated more information on rural infrastructures and environmental matters. Viewed from the perspective of editor's enhanced academic background, the rising educational profile of members of the public and the synergy between environment, health and rural development, newspapers need to improve on their advocacy role in order to enhance their credibility as promoters of issues of public interest.
\end{abstract}

Key words: Print media, Content analysis, Advocacy journalism, Rural development, Environmental management.

\subsection{INTRODUCTION}

Adoption of innovations is crucial for modernization and development of rural communities in Nigeria . Cognizant of this fact, the Federal Government of Nigeria formulated policies and designed programmes aimed at establishing foundations of self reliance, and ensuring maximum utilization of human and material resources. Nigeria's rural development strategy shifted from sectoral to integrated approach, with emphasis on multi-dimensional elements such as territorial reorganization, infrastructural development as well as lands, agrarian and institutional reforms (Mabogunje, 1992) in order to enhance rural aesthetics and stem rural-urban migration. 


\section{Journal of Agricultural Extension}

Vol. 12 (2) December, 2008

A number of technology development and transfer pathways, and approaches have been adopted in Nigeria over the years. The Nigerian society has indeed, evolved from an illiterate, pre-industrial setting, with small homogenous populations living in contiguous neighborhoods, to an anonymous and dynamic mass society where direct communication is difficult because of a large scattered and heterogeneous population whose interpersonal relations are characteristically formal and secondary and under an organized industrial environment (Igbo, 2003). Consequently, folk media such as story telling, songs, myths, masquerades and puppet shows, which served as traditional channels for education and diffusing societal mores and values within the society, and from one generation to another (ljioma,1998), are gradually fading away. As we leave the information age and enter the communications age (Ezell, 1989), the traditional channels are now ineffective and are being replaced with sophisticated information and communication technologies which are capable of reaching a larger audience in a shorter space of time. Mass media channels (radio, television, computer, newspaper) have revolutionalized information delivery to a mass audience simultaneously, thereby overcoming problems faced by interpersonal channels.

Newspaper publication started in Nigeria in 1859 and today, there are quite a number of government and privately -owned newspapers in the country varying in frequency and time of publication as well as circulation rate, target audience and achievements. One of the primary functions of the newspaper is to objectively report news situation or events in all fields of human endeavor. Usually, management of the print media assesses the newsworthiness of events and based on the philosophy and interests of the organization, takes the decision on how best to present or showcase news events to achieve maximum effect.

Newspaper messages are durable. Produced as tabloids or standard newspapers, their pages basically contain news items presented as editorials, features or advertorials. The news behind the news (Eze, 1995), or stories explaining the background of news events, the personality highlights surrounding them, the relationship to other news, and future development the news might cause (Emery et al, 1973) appear as features stories. Newspapers also set aside display and classified columns to assist producers and establishments to run advertisement campaigns. When advertising is used to present a controversial public issue, it is called advocacy advertising (ljioma, 1980)

To what extent is the print media, and particularly the newspaper, serving or promoting agricultural and rural development issues of public interest in Nigeria? This study provides an answer to this question as the procedure adopted (content analysis) gives clue to editor's or writer's intentions and to the kind of audience which a publication or broadcast attracts. It also serves the purpose of describing trends in communication, analyzing techniques for persuasion, and relating known attributes of the audience to messages produced for them (Hoslti, 1969).

\subsection{OBJECTIVE OF THE STUDY}

This study was undertaken to ascertain the roles of newspapers in aiding agricultural and rural development in Nigeria. It measured the achievements of the newspapers in rural development information diffusion, and the focus was on seven components of rural development: agriculture, nutrition, health, population/ family planning, environmental quality, road construction/maintenance and rural electrification. 
Specifically, the quarterly trend in news coverage of these components was analyzed and the reportorial approach and depth compared for the newspapers studied.

\subsection{METHODOLOGY}

The study content-analyzed five (5) major national news dailies, namely, The Champion, The Sun, ThisDay, The Guardian and The Punch. This is out of over twenty newspapers published daily in Nigeria. Content-analysis is a practice of measuring and analyzing communication that has taken place, and from it make inferences (Ogunbameru, 2000, Kerlinger, 1986). The study spanned a period of twelve (12) calendar months, (January-December) in 2006. Newspaper coverage and reportage of rural development and environmental preservation activities were reviewed for each quarter of the year. Apart from quantitatively ascertaining how newspapers handled rural development news items, the mode of reporting adopted in presenting such information was also reviewed. Strategies adopted were content definition, content categorization and counting or quantification (Farinde, 2004). In other words, articles considered relevant were identified; classified and enumerated using percentages and frequency counts, and the results were presented with tables.

\subsection{RESULTS AND DISCUSSION}

\section{Quarterly Trends in Newspaper Coverage}

Data in Table 1 show that the newspapers showed some concern and addressed rural development matters in 2006. However, the quantitative variation on performance of the papers were quite narrow.

\section{$\mathbf{Q}_{1}$ Performance (January-March, 2006)}

The Punch newspaper's accomplishments in the first quarter of the year was the highest $(32.85 \%)$, followed closely by those of The Sun $(24.7 \%)$, The Champion (16.7\%), The Guardian (15\%) and ThisDay (10.07\%) newspapers, Agriculture/nutrition issues (32.58\%) infrastructures were the most widely reported in this quarter, followed by health $(31.07 \%)$ and rural infrastructures(17.5\%). The high intensity of agricultural activities that take place in the first quarter of every year may have accounted for this. The farming calendar and activity schedule of Agricultural Development Programmes (ADPs) shows that farming activities in some parts of the country are usually at their in the first quarter of the year. This is the period of land preparation, planting of arable crops, establishment of nurseries for agro-forestry, fadama dry season vegetable establishment and routine animal husbandry practices. Sometimes cropping outside the south-south agro-ecological zone does not start until April which is in the second quarter. 
TABLE 1: Coverage of rural development new: January - March, 2006

\begin{tabular}{lcccccc}
\hline \multicolumn{1}{c}{ Sub-sectors } & $\begin{array}{c}\text { Daily } \\
\text { Champion }\end{array}$ & $\begin{array}{c}\text { The } \\
\text { Sun }\end{array}$ & $\begin{array}{c}\text { This } \\
\text { Day }\end{array}$ & $\begin{array}{c}\text { The } \\
\text { Guardian }\end{array}$ & $\begin{array}{c}\text { The } \\
\text { Punch }\end{array}$ & Total \\
Agricultural/Nutrition & 61 & 71 & 46 & 42 & 145 & 365 \\
& $(32.3)$ & $(25.6)$ & $(38.3)$ & $(25.0)$ & $(39.4$ & \\
Health & 30 & 158 & 30 & 49 & 81 & 348 \\
& $(17.7)$ & $(57.1)$ & $(25.0)$ & $(28.6)$ & $(22.01)$ & \\
Population/family & 20 & 9 & 6 & 29 & 21 & 85 \\
Planning & $(9.7)$ & $(3.3)$ & $(5.0)$ & $(17.9)$ & $(5.71)$ & \\
Environmental & 25 & 10 & 15 & 22 & 54 & 85 \\
Education & $(12.9)$ & $(3.6)$ & $(12.5)$ & $(13.09)$ & $(14.7)$ & \\
Rural & 51 & 29 & 23 & 26 & 67 & 196 \\
Infrastructures & $(27.4)$ & $(10.5)$ & $(19.2)$ & $(16.0)$ & $(18.2$ & \\
\multicolumn{1}{c}{ Total } & $187(100)$ & 277 & 120 & $168(100)$ & $368(100$ & 1120 \\
& & $(100)$ & $(100)$ & & & \\
\hline
\end{tabular}

Source: Field survey, 2007; NB: Figures in parenthesis represent percentage scores

\section{$Q_{2}$ Performance (April-June, 2006)}

Agriculture/Nutrition news reportage fell by 6 percent from the first to the second quarter. This period $\left(Q_{2} 2006\right)$ also saw a drop by 2 percent in rural infrastructures news coverage. Health news rose marginally by $0.13 \%$ during the period. The Punch newspapers led the pack $(27.89 \%)$ in rural development news coverage and presentation in this quarter, though with some level of depreciation against $Q_{1} 2006$ performance $(33.8 \%)$. The Sun newspapers gave minimal attention to rural development matters (13.73\%).

The health sub-sector dominated press attention $(31.20 \%)$ in the second quarter, followed by agriculture / nutrition (26.88\%) and environmental matters $(17.18 \%)$. Apart from increased global concern for preventive and curative healthcare, the activities of the world health Day held on $7^{\text {th }}$ April, 2006 may have positively influenced media attention to health issues in this quarter. Again a priori expectation was a very high level of reportage of environmental issues in the second quarter of the year. This is because it coincided with the period the nation joined other countries in commemorating the World Environment Day which took place on $5^{\text {th }}$ June, 2006. Activities of the world health or environmental day celebration period that deserve publicity include keynote addresses and goodwill messages, clean-up exercise, awareness/sensitization campaigns, and workshops on industrial and domestic waste management. Others are tree planting activities, lectures, excursion, and art and essay competitions. The fact that information diffused by newspapers about the environment was relatively low in this quarter, and even fell by four percent in the third quarter of the year, suggests a serious newspaper under reporting of events in the rural development sub-sector. 
TABLE 2: Coverage of Rural Development News, April-June, 2006

\begin{tabular}{lcccccc}
\hline \multicolumn{1}{c}{ Sub-sectors } & $\begin{array}{c}\text { Daily } \\
\text { Champion }\end{array}$ & $\begin{array}{c}\text { The } \\
\text { Sun }\end{array}$ & $\begin{array}{c}\text { This } \\
\text { Day }\end{array}$ & $\begin{array}{c}\text { The } \\
\text { Guardian }\end{array}$ & $\begin{array}{c}\text { The } \\
\text { Punch }\end{array}$ & Total \\
Agricultural/Nutrition & 77 & 53 & 70 & 72 & 102 & 374 \\
& $(26.6)$ & $(27.7)$ & $(21.1)$ & $(29.5)$ & $(30.2)$ & \\
Health & 64 & 55 & 158 & 54 & 103 & 434 \\
& $(23.4)$ & $(28.8)$ & $(47.6)$ & $(22.1)$ & $(30.5)$ & \\
Population/family & 42 & 37 & 17 & 13 & 25 & 134 \\
Planning & $(13.8)$ & $(19.4)$ & $(5.1)$ & $(5.3)$ & $(7.4)$ & \\
Environmental & 57 & 35 & 44 & 52 & 25 & 239 \\
Education & $(20.2)$ & $(18.3)$ & $(13.2)$ & $(21.3)$ & $(15.1)$ & \\
Rural & 46 & 11 & 43 & 53 & 57 & 210 \\
Infrastructures & $(16.0)$ & $(5.8)$ & $(12.9)$ & $(21.7)$ & $(16.9)$ & \\
\multicolumn{1}{c}{ Total } & $286(100)$ & 191 & 332 & $244(100)$ & 338 & 1391 \\
& & $(100)$ & $(100)$ & & $(100)$ & \\
\hline
\end{tabular}

Source: Field Survey, 2007; NB: Figures in Parenthesis represent percentage scores

\section{$Q_{3}$ Performance (July-September, 2006)}

The Champion newspapers outclassed all the others (32.0\%) in rural development information dissemination in the third quarter of 2006. The Guardian and The Sun newspapers followed closely with $20.88 \%$ and $18.17 \%$, respectively. Agriculture/nutrition received the highest $(28.26 \%)$ level of publicity in this quarter, followed by health $(26.10 \%)$ and population/family planning $(18.04 \%)$. The attention given to population/family planning issues by the newspapers is, therefore, considered inadequate considering the fact that 2006 was a census year in Nigeria, and the World Population Day celebrations took place on July 11, 2006 which was in the third quarter. Population matters, and particularly the conduct of population census and vital registration exercise, deserved wider publicity from the media during this period than it was given.

\section{$\mathbf{Q}_{4}$ Performance (October-December,2006)}

Compared to $Q_{3} 2006$, rural development news coverage in agriculture/nutrition and population/family planning sub-sectors dropped by four and two percent respectively in the $Q_{4} 2006$. This is in spite of the fact that the World Food Day was celebrated on October 16, 2006 which was in this quarter. Newspaper coverage of health, environmental, and rural infrastructures issues appreciated by between 2 and 3 percent during this same period. 
Journal of Agricultural Extension

Vol. 12 (2) December, 2008

TABLE 3: Coverage of rural development news, July-September, 2006

\begin{tabular}{lcccccc}
\hline \multicolumn{1}{c}{ Sub-sectors } & $\begin{array}{c}\text { Daily } \\
\text { Champion }\end{array}$ & $\begin{array}{c}\text { The } \\
\text { Sun }\end{array}$ & $\begin{array}{c}\text { This } \\
\text { Day }\end{array}$ & $\begin{array}{c}\text { The } \\
\text { Guardian }\end{array}$ & $\begin{array}{c}\text { The } \\
\text { Punch }\end{array}$ & Total \\
Agricultural/Nutrition & 50 & 41 & 40 & 76 & 42 & 249 \\
& $(17.90)$ & $(20.0)$ & $(35.0)$ & $(41.3)$ & $(29.8)$ & \\
Health & 85 & 42 & 21 & 39 & 43 & 230 \\
& $(30.5)$ & $(28.0)$ & $(17.5)$ & $(21.2)$ & $(30.5)$ & \\
Population/family & 68 & 31 & 14 & 44 & 2 & 159 \\
Planning & $(23.2)$ & $(20.0)$ & $(12.5)$ & $(23.4)$ & $(1.4)$ & \\
Environmental & 35 & 32 & 30 & 7 & 12 & 116 \\
Education & $(12.6)$ & $(20.0)$ & $(27.5)$ & $(3.80)$ & $(8.50)$ & \\
Rural & 44 & 14 & 9 & 18 & 42 & 127 \\
Infrastructures & $(115.8)$ & $(12.0$ & $(7.5)$ & $(9.8)$ & $(29.8)$ & \\
\multicolumn{1}{c}{ Total } & $2829(100)$ & 160 & 144 & $184(100)$ & 141 & 881 \\
& & $(100)$ & $(100)$ & & $(100)$ & \\
\hline
\end{tabular}

Source: Field Survey, 2007; NB: Figures in parenthesis represent percentage scores

The yuletide period witnesses the launching of many community development projects, hence there is usually a lot to report about basic infrastructural (feeder roads, electricity, etc) development in the fourth quarter of the year. The Sun newspapers' coverage of rural development news in this quarter was highest $(34.50 \%)$, followed by The Champion (19.24\%) and The Guardian (19.05\%). The health sector received the highest level $(27.80 \%)$ of press attention, followed by agriculture/nutrition $(24.05 \%)$, rural infrastructures $(17.12 \%)$, population/family planning $(15.77 \%)$ and environmental issues $(15.20 \%)$.

\section{Comparison of Approach, Depth and Variety of News Reportage}

Findings of this research work indicate that the newspapers utilized a variety of methods to achieve their goals of informing, educating and entertaining. The details are presented in Tables 5-8. 
TABLE 4: Coverage of rural development news, October-December, 2006

\begin{tabular}{lcccccc}
\hline \multicolumn{1}{c}{ Sub-sectors } & $\begin{array}{c}\text { Daily } \\
\text { Champion }\end{array}$ & The Sun & $\begin{array}{c}\text { This } \\
\text { Day }\end{array}$ & $\begin{array}{c}\text { The } \\
\text { Guardian }\end{array}$ & $\begin{array}{c}\text { The } \\
\text { Punch }\end{array}$ & Total \\
Agricultural/Nutrition & 69 & 136 & 42 & 67 & 61 & 375 \\
& $(22.5)$ & $(25.3)$ & $(25.9)$ & $(22.6)$ & $(22.8)$ & \\
Health & 51 & 132 & 51 & 60 & 140 & 434 \\
& $(17.2)$ & $(24.5)$ & $(32.7)$ & $(20.0)$ & $(52.2)$ & \\
Population/family & 53 & 123 & 25 & 31 & 14 & 237 \\
Planning & $(17.2)$ & $(22.9)$ & $(15.4)$ & $(10.4)$ & $(5.2)$ & \\
Environmental & 53 & 82 & 12 & 65 & 25 & 237 \\
Education & $(18.3)$ & $(15.2)$ & $(7.7)$ & $(24.9)$ & $(10.5)$ & \\
$\quad$ Total & $300(100)$ & $538(100)$ & $156(100)$ & $297(100)$ & $268(100)$ & 1559 \\
\hline
\end{tabular}

Source: Field Survey, 2007; NB Figures in parenthesis represent percentage scores

\section{Editorials}

The Sun newspapers editorial/opinion offerings in the rural development sector was highest $(33.4 \%)$, followed by that of The Punch $(26.2 \%)$, and The Champion $(19.50 \%)$ (Table5). This Day newspapers utilized their editorial column least $(9.59 \%)$ in rural development advocacy.

TABLE 5: Rural development information reportorial approach, 2006

\section{Editorials}

\begin{tabular}{lcccccc}
\hline Newspaper & $\begin{array}{c}\text { Agriculture } \\
\text { Nutrition }\end{array}$ & Health & $\begin{array}{c}\text { Population } \\
\text { family } \\
\text { planning }\end{array}$ & $\begin{array}{c}\text { Environmental } \\
\text { Education }\end{array}$ & $\begin{array}{c}\text { Rural } \\
\text { Infrastructures }\end{array}$ & Total \\
The & 26 & 24 & 23 & 23 & 30 & 126 \\
Champion & $(20.64)$ & $(19.05)$ & $(18.25)$ & $(18.25)$ & $(23.81)$ & $(100)$ \\
The Sun & 40 & 83 & 34 & 38 & 21 & 216 \\
This Day & $(18.52)$ & $(38.43)$ & $(15.74)$ & $(17.59)$ & $(9.72)$ & $(100)$ \\
The & 19 & 19 & 6 & 7 & 11 & 62 \\
Guardian & $(30.64)$ & $(30.64)$ & $(9.68)$ & $(11.29)$ & $(17.74)$ & $(100)$ \\
The Punch & 13 & 18 & 16 & 13 & 13 & 73 \\
\multicolumn{1}{c}{ Total } & $63.80)$ & $(24.66)$ & $(21.92)$ & $(17.81)$ & $(17.81$ & $(100)$ \\
& $(37.28)$ & $(14.79)$ & $(6.51)$ & $(12.42)$ & $(28.99)$ & $(100)$ \\
\hline
\end{tabular}

Source: Field Survey, 2007; NB: Figures in parenthesis represent percentage scores

The health sub-sector received the highest editorial attention (26.16\%), followed by agriculture/nutrition (25\%). And rural infrastructures (19\%). Population/Family planning issues received the least editorial attention $(14.0 \%)$, with a rating that was slightly below that on environmental matters (16.0\%). Newspapers comment editorially on contemporary issues. It is common to find opinion materials, written in a formal style, being used to fill the editorial slots as well bylines and signed editorial columns of newspapers. 
Journal of Agricultural Extension

Vol. 12 (2) December, 2008

\section{Features stories}

As illustrated in Table 6, The Champion newspaper devoted the largest portion of its space $(23.84 \%)$ to feature stories on rural development, followed by The Punch $(22.84 \%)$ and The Sun newspapers $(19.17 \%)$. Features articles in the health subsector predominated $(29.0 \%)$, followed by those in agriculture / nutrition $(27 \%)$. Population / family planning matters received the least attention (14\%) as features stories.

TABLE 6: Rural development information reportorial approach, 2006

\section{Features}

\begin{tabular}{lcccccc}
\hline Newspaper & $\begin{array}{c}\text { Agriculture } \\
\text { Nutrition }\end{array}$ & Health & $\begin{array}{c}\text { Population } \\
\text { family } \\
\text { planning }\end{array}$ & $\begin{array}{c}\text { Environmental } \\
\text { Education }\end{array}$ & $\begin{array}{c}\text { Rural } \\
\text { Infrastructures }\end{array}$ & Total \\
The & 202 & 181 & 136 & 127 & 173 & 818 \\
Champion & $(24.69)$ & $(22.12)$ & $(16.62)$ & $(15.53)$ & $(21.15)$ & $(100)$ \\
The Sun & 189 & 161 & 147 & 99 & 62 & 658 \\
This Day & $(28.72)$ & $(24.46)$ & $(22.34)$ & $(15.05)$ & $(9.42)$ & $(100$ \\
The & 152 & 204 & 50 & 67 & 71 & 544 \\
Guardian & $(27.94)$ & $(37.50)$ & $9.19)$ & $(12.32)$ & $(13.05)$ & $(100)$ \\
The Punch & 183 & 139 & 87 & 97 & 116 & 622 \\
& $29.42)$ & $(22.35)$ & $(13.99)$ & $(15.59)$ & $(18.65)$ & $(100)$ \\
\multicolumn{1}{c}{ Total } & $(26.36)$ & $(38.02)$ & $(57.03)$ & $(12.80)$ & $(17.11)$ & $(100)$ \\
\hline
\end{tabular}

Source: Field survey, 2007; NB: Figures in parenthesis represent percentage scores

\section{Advertorials}

Data in table 7 show that the use of newspaper as an advertising medium for rural development messages in 2006 was highest in the Sun Newspapers $(47.0 \%)$, And least in the champion newspapers (7.6\%). This Day, The Punch and The Guardian newspapers used their medium less extensively in luring the public to rural development programmes and services. The health sub-sector received the highest proportion of advertorials (44.0\%), followed by agriculture / nutrition (32\%). Each of the other sub-sectors had less than 20 percent. 
TABLE 7: Rural development information reportorial approach, 2006

\section{Advertorials}

\begin{tabular}{lcccccc}
\hline Newspaper & $\begin{array}{c}\text { Agriculture } \\
\text { Nutrition }\end{array}$ & Health & $\begin{array}{c}\text { Population } \\
\text { family } \\
\text { planning }\end{array}$ & $\begin{array}{c}\text { Environmental } \\
\text { Education }\end{array}$ & $\begin{array}{c}\text { Rural } \\
\text { Infrastructures }\end{array}$ & Total \\
The & 15 & 10 & 7 & 0 & 3 & 35 \\
Champion & $(42.85)$ & $(28.57$ & $(20.0)$ & $(0.0)$ & $8.57)$ & $(100)$ \\
The Sun & 53 & 127 & 7 & 2 & 27 & 216 \\
This Day & $(24.85)$ & $(58.79)$ & $(3.24)$ & $(0.93)$ & $(12.50)$ & $(100)$ \\
The & 18 & 21 & 2 & 21 & 10 & 72 \\
Guardian & $(25.0)$ & $(29.16)$ & $(2.78)$ & $(29.17)$ & $(13.88)$ & $(100)$ \\
The Punch & 25 & 25 & 1 & 3 & 9 & 63 \\
& $39.68)$ & $(39.68)$ & $(1.59)$ & $(4.76)$ & $(14.29)$ & $(100)$ \\
Total & $152.05)$ & $(30.14)$ & $(6.85)$ & $(5.47)$ & $(5.47)$ & $(100)$ \\
\hline
\end{tabular}

Source: Field Survey, 2007; NB: Figures in parenthesis represent percentage scores

\section{Pictorials}

The Guardian newspapers showed the highest level of involvement in photo documentation of rural development news $(32.53 \%$ ) in 2006 (Table 8 ). It was closely followed by The Punch newspapers $(20.24 \%)$ and This day newspapers $(10.60 \%)$. Pictures/cartoons were used most frequently in disseminating agriculture/nutrition messages $(29.0 \%)$, followed by environmental $(23.0 \%)$, health $(21.0 \%)$ and population/family planning messages $(11.0 \%)$. 
Journal of Agricultural Extension

Vol. 12 (2) December, 2008

TABLE 8: Rural development information reportorial approach, 2006

Pictorials

\begin{tabular}{lcccccc}
\hline Newspaper & $\begin{array}{c}\text { Agriculture } \\
\text { Nutrition }\end{array}$ & Health & $\begin{array}{c}\text { Population } \\
\text { family } \\
\text { planning }\end{array}$ & $\begin{array}{c}\text { Environmental } \\
\text { Education }\end{array}$ & $\begin{array}{c}\text { Rural } \\
\text { Infrastructures }\end{array}$ & Total \\
The & 14 & 15 & 17 & 20 & 10 & 76 \\
Champion & $(18.42)$ & $(19.74)$ & $(22.36)$ & $(26.32)$ & $(13.16)$ & $(100)$ \\
The Sun & 19 & 16 & 12 & 20 & 9 & 76 \\
This Day & $(25.0)$ & $(21.05)$ & $(15.78)$ & $(23.31)$ & $(11.84)$ & $(100)$ \\
The & 9 & 16 & 4 & 6 & 9 & 44 \\
Guardian & $(20.45)$ & $(36.36)$ & $(9.09)$ & $(13.63)$ & $(20.45)$ & $(100)$ \\
The Punch & 36 & 20 & 13 & 33 & 33 & 135 \\
\multicolumn{1}{c}{ Total } & 41 & $14.81)$ & $(9.63)$ & $(24.44)$ & $(24.44)$ & $(100)$ \\
\hline
\end{tabular}

Source: Field survey. 2007; NB: Figures in parenthesis represent percentage scores

\subsection{CONCLUSION}

The economic, health and ethical imperatives for sustainable agricultural and rural development and for environmental education place enormous burden on a number of stakeholders as well as on the mass media whose statutory responsibilities include ecological vigilance, environmental and agricultural education. Generally speaking, a reasonable effort was made by the newspapers to cover agricultural and environmental matters in 2006. Daily Champion newspapers performed best in overall advocacy for rural development and environmental conservation in 2006, followed by The Punch and The Guardian newspapers. These publishing outfits seem to have understood that educating members of the public on agricultural and food security measures, as well as on global and national environmental problems is part of their responsibilities. It is only right and necessary for the other mass media outfits to follow this trend by monitoring and regulating government and private agencies responsible for enforcing environmental laws and regulations, and to report breach of such provisions on their pages. Newspapers are readily available in most cities of the country. Furthermore, the level of education of the average Nigerian has so improved that he can decipher ideas presented either in words or pictorially. Newspapers cannot afford to abdicate their advocacy responsibilities as Nigeria pursues her vision and goal of having a safe and healthy environment that secures the economic and social well-being of the present and future generations. 


\section{References}

Emery, E. Ault, P.H., and Agee W. K. (1973). Introduction to Mass Communication, $4^{\text {th }}$ Ed. Dodd, Mead and Co., New York,464p.

Eze, N.C. (1995). Journalism and Christian Writing. Evangel Press Limited Aba, 120 pp.

Ezell, M. P. (1989). Communication - age trends affecting extension: future technological and organizational trends. Journal of Extension; USA P. 22.

Farinde, A. J. (2004). Qualitative data collection in agricultural extension research. In: T. Olowu (Ed.) AESON-Research Methods in Agricultural Extension ARMTI, llorin, 140 pp.

Federal Ministry of Agriculture, Water Resources and Rural Development (FMAWRRD). (1987). Agricultural Policy for Nigeria, Lagos. 65 pp.

Gangwari, J. U. (1993). The Origin of the Communication Media in Nigeria Anet Productions Itd. Jos, 30 pp.

Hoslti, O. R. 91969). Content Analysis for the Social Sciences and Humanities, Mc Addison . Wesley, Reading.

Igbo, E.M. (2003). Basic Sociology. $1^{\text {st }}$ ed. Cidjap Press, Enugu.

ljioma, C.I. (1998). Essential Readings in Mass Communication. Onek Company Nigeria, Aba, 155 pp.

Kerlinger, F. N. (1986). Foundation of Behavioural Research $\left(3^{\text {rd } E d .), ~ H a r c o u r t ~ B r u c e ~}\right.$ College Publishers, New York, 741 pp.

Mabogunje, A. (1992). Integrated Rural Development. Social Transformation for self Reliance: Proceedings of a MAMSER National Conference. Fountain Publications, Ibadan, Nigeria $386 \mathrm{pp}$.

Mc. Quail, D. (1980). An Introduction to Mass Communication Theory. Sage Publications Ltd.

Ogunbameru, O. A. (2000). Introducing Social, Research and Report Writing. First Edition. Pat Mag Press, Mokola, Ibadan, p.71-99.

Zaria, M.B. 91987). The Use of Radio in Extension Work. Training Handout at the Communcation Skill Workshop for Eield Extension Workers. NAERLS, Zaria. 